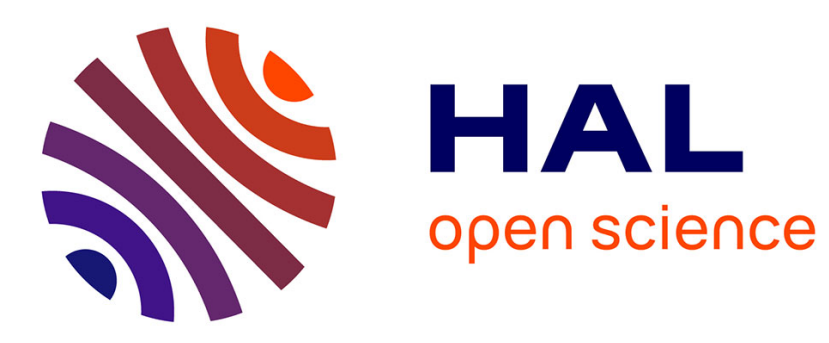

\title{
Metals in aqueous solutions and real effluents: Biosorption behavior onto a hemp-based felt
}

Sonia Loiacono, Grégorio Crini, Gilles Chanet, Marina Raschetti, Vincent Placet, Nadia Crini

\section{- To cite this version:}

Sonia Loiacono, Grégorio Crini, Gilles Chanet, Marina Raschetti, Vincent Placet, et al.. Metals in aqueous solutions and real effluents: Biosorption behavior onto a hemp-based felt. Journal of Chemical Technology and Biotechnology, 2018, 93 (9), pp.2592 - 2601. hal-02130081

\section{HAL Id: hal-02130081 \\ https://hal.science/hal-02130081}

Submitted on 15 May 2019

HAL is a multi-disciplinary open access archive for the deposit and dissemination of scientific research documents, whether they are published or not. The documents may come from teaching and research institutions in France or abroad, or from public or private research centers.
L'archive ouverte pluridisciplinaire HAL, est destinée au dépôt et à la diffusion de documents scientifiques de niveau recherche, publiés ou non, émanant des établissements d'enseignement et de recherche français ou étrangers, des laboratoires publics ou privés. 
Metals in aqueous solutions and real effluents: Biosorption behavior onto a hemp-based felt

(Short title: Metal removal by a hemp-based felt)

\author{
Sonia Loiacono ${ }^{1}$, Grégorio Crini ${ }^{1}$, Gilles Chanet $^{2}$, Marina Raschetti ${ }^{3}$, Vincent Placet ${ }^{3}$, Nadia \\ Morin-Crini ${ }^{1, *}$ \\ ${ }^{1}$ UMR 6249 Chrono-environnement, Université de Bourgogne Franche-Comté, 16 route de \\ Gray, 25000 Besançon, France \\ ${ }^{2}$ Eurochanvre, 7 route de Dijon, 70100 Arc-les-Gray, France \\ ${ }^{3}$ FEMTO-ST Institute, CNRS/UFC/ENSMM/UTBM, Department of Applied Mechanics, \\ Université de Bourgogne Franche-Comté, 25000 Besançon, France.
}

This paper is dedicated to the memory of Peter Winterton.

\begin{abstract}
BACKGROUND: In this study, a hemp-based material in the form of a felt is used to adsorb metals in individual aqueous solutions and in polycontaminated effluents using the batch method. The factors affecting the biosorption process were initial metal concentration, biosorbent dosage, contact time and $\mathrm{pH}$.

RESULTS: In controlled conditions, results showed that: (i) the felt exhibited high adsorption capacities towards metals in the following order: $\mathrm{Pb}>\mathrm{Cd}>\mathrm{Cu}>\mathrm{Zn}>\mathrm{Co} \sim \mathrm{Fe} \sim \mathrm{Ni} \sim \mathrm{Cr} \sim$ Al Mn; (ii) no significant differences were observed for the three salts used (sulfate, chloride and nitrate); (iii) the process was rapid: $10 \mathrm{~min}$ were sufficient to attain equilibrium; iv) the biosorption efficiency increased considerably with the increase of the biosorbent dosage; and (v) the adsorption capacities were independent of $\mathrm{pH}$ between 4 - 6. The maximum adsorption capacities for $\mathrm{Cd}, \mathrm{Cu}, \mathrm{Zn}, \mathrm{Co}, \mathrm{Fe}, \mathrm{Ni}, \mathrm{Cr}, \mathrm{Al}$ and $\mathrm{Mn}$ were 27.47, 14.64, $10.59,7.99,7.85,7.87,6.53,6.38$ and $4.55 \mathrm{mg} / \mathrm{g}$, respectively. Interesting results were also obtained for real polymetallic effluents. Ecotoxicological tests also confirmed the efficiency of the biosorption to radically decrease the effluent toxicity.
\end{abstract}

CONCLUSIONS: Based on these results, hemp-based felt could serve as a novel and efficient biosorbent material for pollutant removal from industrial effluents.

* Correspondence to: N. Morin-Crini (E-mail: nadia.crini@univ-fcomte.fr)

This article has been accepted for publication and undergone full peer review but has not been through the copyediting, typesetting, pagination and proofreading process, which may lead to differences between this version and the Version of Record. Please cite this article as doi: $10.1002 /$ jctb.5612 
Keywords:

Hemp, Biosorption, Metals, Wastewater, Batch experiments

\section{Introduction}

The chemical contamination of water by a wide range of metals is a serious environmental problem involving potential human toxicity. Therefore, there is a need to develop technologies that can remove toxic substances including metals from wastewaters. Biosorption using non-conventional natural materials has been proposed as an economical and effective method to adsorb metals present in aqueous solutions at trace levels over traditional treatment methods such as membrane filtration, evaporation, adsorption onto activated carbons, and ion-exchange or chelation using organic resins. ${ }^{1-9}$

An important class of new materials is based on the use of hemp, an annual high yielding industrial crop grown for its fibers and seeds. Hemp is an interesting raw material because of its low-cost, readily availability, particular chemical composition of its fibres, mainly cellulose (over 75\%), and for its versatility. ${ }^{10}$ Applications are found in numerous sectors of industry, including pulp and paper, textiles, construction, automotive applications, composites (plastic, packaging), agrochemistry, food-chemistry, cosmetics and essential oils, pharmacy and medicine, adhesives and biotechnology. In recent years, hemp-based materials have been proposed for metal ion removal from aqueous synthetic solutions. Abundant data on this topic can be found in the literature. ${ }^{1-19}$ However, these published works focus on the removal of metals present in synthetic solutions using hemp in fibre form.

In this study, we propose the use of a hemp-based material in the form of felt to treat metals present in monometallic aqueous solutions or in polycontaminated effluents. The metal studied are: $\mathrm{Al}, \mathrm{Cd}, \mathrm{Co}, \mathrm{Cr}, \mathrm{Cu}, \mathrm{Fe}, \mathrm{Mn}, \mathrm{Ni}, \mathrm{Pb}$ and $\mathrm{Zn}$. They are chosen for two reasons: firstly these metals (except $\mathrm{Cd}$ ) are studied due to their common presence in discharge waters from the metal industry, and secondly, six metals $(\mathrm{Cd}, \mathrm{Cu}, \mathrm{Cr}, \mathrm{Ni}, \mathrm{Pb}$ and $\mathrm{Zn})$ are included in the list of priority pollutants defined by the French Water Agency (French Circular, July 27, 2015). Here different controlling experimental conditions are investigated and discussed. The main parameters studied were initial metal concentration, effect of counter-ions (sulfate, nitrate and chloride metallic salts) biosorbent dosage, contact time and $\mathrm{pH}$. We also report the performance of hemp-based felt to treat a mixture of metals present in industrial effluents. 


\section{Material and methods}

\subsection{Material}

The hemp-based material was provided by the French company Eurochanvre (HauteSaône, France). The hemp felt was made of $100 \%$ fibre. Its characteristics are reported in Table 1 . Before use, the material was extensively washed in reverse osmosis $(\mathrm{RO})$ water $(\mathrm{pH}$ $=5.0 \pm 0.1)$ and then dried at $60^{\circ} \mathrm{C}$ to constant weight. ${ }^{20}$

\section{Table 1}

\subsection{Metals}

$\mathrm{Al}_{2}\left(\mathrm{SO}_{4}\right)_{3} \cdot 16 \mathrm{H}_{2} \mathrm{O}, \mathrm{CdSO}_{4} \cdot 8 \mathrm{H}_{2} \mathrm{O}, \mathrm{CdCl}_{2}, \mathrm{CoSO}_{4} \cdot 7 \mathrm{H}_{2} \mathrm{O}, \quad \mathrm{CoCl}_{2} \cdot 6 \mathrm{H}_{2} \mathrm{O}, \mathrm{Co}\left(\mathrm{NO}_{3}\right)_{2} \cdot 6 \mathrm{H}_{2} \mathrm{O}$, $\mathrm{CrK}\left(\mathrm{SO}_{4}\right)_{2} \cdot 12 \mathrm{H}_{2} \mathrm{O}, \quad \mathrm{CuSO}_{4} .5 \mathrm{H}_{2} \mathrm{O}, \quad \mathrm{CuCl}_{2} \cdot 2 \mathrm{H}_{2} \mathrm{O}, \quad \mathrm{FeSO}_{4}, \quad \mathrm{MnSO}_{4} \cdot 4 \mathrm{H}_{2} \mathrm{O}, \quad \mathrm{MnCl}_{2} .2 \mathrm{H}_{2} \mathrm{O}$, $\mathrm{NiSO}_{4} \cdot 6 \mathrm{H}_{2} \mathrm{O}, \mathrm{NiCl}_{2} \cdot 6 \mathrm{H}_{2} \mathrm{O}, \mathrm{Ni}\left(\mathrm{NO}_{3}\right)_{2}, \mathrm{PbSO}_{4}$, and $\mathrm{ZnSO}_{4} \cdot 7 \mathrm{H}_{2} \mathrm{O}$ were purchased from SigmaAldrich (France) and used without further purification. Appropriate weights of each metal were dissolved in RO water to obtain a stock solution containing about $300 \mathrm{mg} / \mathrm{L}$ (except for $\mathrm{Pb}$ for which the concentration of the stock solution was $25 \mathrm{mg} / \mathrm{L}$ due to its poor solubility). Solutions at lower concentrations $(1,10,25,50,100,150$ and 200) were obtained by dilution of the stock solution. All the solutions were analyzed prior to each experiment.

\subsection{Biosorption of metals by batch technique}

Metal removal from solutions (spiked solutions or real effluents) by biosorption on hemp materials was studied by a batch method without changing the initial $\mathrm{pH}$ of the solution $(\mathrm{pH}=$ $5.0 \pm 0.1)$. In each experiment, a fixed mass of felt was introduced into a given metal solution $(100 \mathrm{~mL})$ at a known concentration (for spiked solutions) in a tightly closed flask. The mixture was then mechanically stirred for a given time on a rotating shaker at constant speed $(250 \mathrm{rpm})$ and at room temperature $\left(21 \pm 1^{\circ} \mathrm{C}\right)$. After treatment, the hemp felt was then easily removed and the concentration of the solution was determined by inductively coupled plasma atomic emission spectroscopy (ICP-AES, ThermoFisher, iCAP 6500, Courtaboeuf, France). The biosorption performance was finally calculated and expressed as percentage abatement $(\% \mathrm{R})$. In controlled conditions, initial metal concentration $(1,10,25,50,100,150,200$ and $300 \mathrm{mg} / \mathrm{L})$ in the solution, biosorbent dosage $(0.25,0.5,1,1.5$ and $2 \mathrm{~g})$ and $\mathrm{pH}$ solution (between 1 - 6) were varied to investigate their effect on the biosorption capacity. Studies were also conducted for various time intervals (ranging from 1 - $60 \mathrm{~min}$ ) to determine when biosorption equilibrium was reached. All experiments (controlled conditions or real effluents) 
were run in triplicate and found reproducible (experimental error within 3\%). Blanks were run without any material to determine the extent of metal removal by containers (no adsorption was observed). It was noted that, at the end of the biosorption process, a slight $\mathrm{pH}$ variation of between 0.5 and 0.8 units and between 0.6 and 0.7 units was observed for spiked solutions and real effluents in each experiment, respectively.

\subsection{Analytical methods}

Pollutants were assayed by a certified laboratory following a standard protocol and analyzed by ICP-AES ${ }^{21}$ and results expressed in $\mathrm{mg} / \mathrm{L}$. When the concentrations were lower than the quantification limits (QL) or the detection limits (DL), the values of these limits were taken into account to calculate the percentage abatement. The $\mathrm{pH}$ was measured using a portable pH-meter (model 3110 WTW, Alès, France).

To evaluate changes in the surface morphology of the biosorbent, scanning electron microscopy images (ESEM FEI Quanta 450) with a tungsten filament voltage from $15 \mathrm{keV}$ to $20 \mathrm{keV}$ and low-vacuum conditions were performed. Elemental analysis of the fibre surfaces was also performed using a probe for energy-dispersive X-ray spectroscopy (EDS) and electron beam excitation (with a voltage from $15 \mathrm{keV}$ to $20 \mathrm{keV}$ ).

\subsection{Industrial effluents}

Eight industrial effluents (abbreviated RE for real effluents) were collected for two sampling campaigns (four samples for each campaign taken on four consecutive days, representative samples of a daily activity) from the VMC Pêche metal-finishing factory located in Morvillars (Territoire de Belfort, France). This factory specializes in hook design and production and uses large volumes of water and chemical products, generating volumes of raw effluents about $\sim 40 \mathrm{~m}^{3}$ per day, processed by a physicochemical treatment. This involves several successive steps (coagulation, precipitation, electrocoagulation, flocculation, settling and filtration). The characteristics of eight RE (collected after the first precipitation) are shown in Table 2. The values $(\mathrm{mg} / \mathrm{L})$ described in this table represent the minimal and maximal concentrations obtained for the 8 effluents studied. For this industry, discharge standards should be: Fe $<5 \mathrm{mg} / \mathrm{L}$; Al $5 \mathrm{mg} / \mathrm{L} ; \mathrm{Zn} 2 \mathrm{mg} / \mathrm{L}$, Ni $1 \mathrm{mg} / \mathrm{L}$; Cr $0.5 \mathrm{mg} / \mathrm{L}$, and Cu $0.5 \mathrm{mg} / \mathrm{L}$.

\section{Table 2}

This article is protected by copyright. All rights reserved. 


\subsection{Ecotoxicological tests}

To determine the toxicity of the effluents, a standardized bioassay based on the mobility of Daphnia magna was used..$^{22}$ The toxicity of five samples before and after treatment were studied. Their values were expressed by the EC50, effective concentration corresponding to $50 \%$ inhibition compared to controls (given in percentage of effluent).

\section{Results and discussion}

\subsection{Effect of initial metal concentration}

First, to study the effect of the initial metal concentration on biosorption performance, a series of freshly prepared metal ion solutions was used (solutions prepared with metal sulfate salts). Figure 1 shows the influence of initial metal concentration on the removal of 10 metals in mono-component system (concentrations of 1, 10, 25, 50, 100, 150, 200 and $300 \mathrm{mg} / \mathrm{L}$ for $\mathrm{Al}, \mathrm{Cd}, \mathrm{Co}, \mathrm{Cr}, \mathrm{Cu}, \mathrm{Fe}, \mathrm{Mn}, \mathrm{Ni}$ and $\mathrm{Zn}$, and only 1,10 and $25 \mathrm{mg} / \mathrm{L}$ for $\mathrm{Pb}$ due to its poor solubility). The volume of solution, biosorbent dose and the contact time used in these experiments were $100 \mathrm{~mL}, 1 \mathrm{~g}$ and $60 \mathrm{~min}$, respectively. The results described in Figure 1 show that, up to $25 \mathrm{mg} / \mathrm{L}$, hemp exhibited interesting adsorption capacities ( $\mathrm{R}>60 \%$ ) with the following affinity: $\mathrm{Pb}>\mathrm{Cd}>\mathrm{Cu}>\mathrm{Zn}>\mathrm{Co} \sim \mathrm{Ni} \sim \mathrm{Fe} \sim \mathrm{Cr} \sim \mathrm{Al} \sim \mathrm{Mn}$. At $25 \mathrm{mg} / \mathrm{L}$, the abatement values for $\mathrm{Pb}, \mathrm{Cd}, \mathrm{Cu}, \mathrm{Zn}, \mathrm{Co}, \mathrm{Ni}, \mathrm{Fe}, \mathrm{Cr}, \mathrm{Al}$ and $\mathrm{Mn}$ were 96, 88, 84.5, 77, 70, 68, 67, 67, 66 and 63, respectively. As expected, when the metal concentration was increased, biosorption efficiency decreased, due to the saturation of the biosorption sites on the material. For example, for $\mathrm{Cd}$ and $\mathrm{Cu}$, when the initial metal concentration was increased from $10-300$ $\mathrm{mg} / \mathrm{L}$, the removal decreased from 96 to $35 \%$ and 91 to $24 \%$, respectively.

From Figure 1, at any concentration, the same order of abatement was obtained for all metals studied, so, the affinity was independent of metal concentration. For the concentration range studied (50 - $300 \mathrm{mg} / \mathrm{L}$ ), Cd showed the highest affinity (between $80 \%$ and 35\%) whereas $\mathrm{Mn}$ demonstrated the lowest level of removal (between 48 and 13\%). $\mathrm{Cu}$ also showed interesting affinities (between 78 and 24\%). The difference in the degree of adsorption may be attributed to the physical and chemical characteristics of each metal such as ionic radius, electronegativity and molar mass (Table 3). The ionic radii, molar mass and Allred-Rochow electronegativities decrease in the order $\mathrm{Pb}>\mathrm{Cd}>\mathrm{Mn}>\mathrm{Zn} \sim \mathrm{Fe}>\mathrm{Cu} \sim \mathrm{Co}>\mathrm{Ni}>\mathrm{Cr}>\mathrm{Al}$; $\mathrm{Pb}>\mathrm{Cd}>\mathrm{Zn}>\mathrm{Cu}>\mathrm{Ni} \sim \mathrm{Co}>\mathrm{Fe}>\mathrm{Mn}>\mathrm{Cr}>\mathrm{Al}$, and $\mathrm{Cu} \sim \mathrm{Ni} \sim \mathrm{Co}>\mathrm{Fe} \sim \mathrm{Mn} \sim \mathrm{Zn}>\mathrm{Cr} \sim$ $\mathrm{Pb}>\mathrm{Cd} \sim \mathrm{Al}$, respectively. However, the two largest ions, lead and cadmium, for which 
affinities were high, indicated that the size of ions, the molar mass and the electronegativity were not the only determining parameter in the adsorption process. Similar conclusions were reached by Pejić et al. ${ }^{16,17}$ and Kyzas et al. ${ }^{19}$.

\section{Table 3}

\section{Figure 1.}

\subsection{Effect of counter-ions on metal biosorption}

The effect of counter-ions in a biosorption system is an important issue as real effluents can contain anions other than sulfate, such as nitrate and chloride. The effect of counter-ions on the biosorption of $\mathrm{Ni}$ and Co by hemp is represented in Figure 2. For these two metals no significant differences in the abatement were observed for the three salts used (sulfate, chloride and nitrate). Similar results were obtained for other metals.

\section{Figure 2.}

\subsection{Effect of biosorbent dose}

Metal biosorption on hemp material was studied by changing the amount of biosorbent $(0.25$, $0.5,1,1.5$, and $2 \mathrm{~g})$ added to sample at different initial metal concentrations $(25,50,100,150$, 200 and $300 \mathrm{mg} / \mathrm{L})$ while maintaining the volume $(100 \mathrm{~mL})$, the contact time $(60 \mathrm{~min})$ and the agitation speed $(250 \mathrm{rpm})$ constant. The results (Figure 3) showed that metal removal increased with the mass of biosorbent reaching equilibrium between $1 \mathrm{~g}$ (for $\mathrm{Cd}, \mathrm{Cu}$ and $\mathrm{Pb}$ ) and $1.5 \mathrm{~g}$ (for $\mathrm{Zn}, \mathrm{Ni}, \mathrm{Co}, \mathrm{Mn}, \mathrm{Fe}, \mathrm{Cr}, \mathrm{Al}$ ) of added material. As expected, this overall trend corresponds to the increase of the interactions between biosorbing material and metals, due to the higher biosorbent surface area, and thus the available active sites.

\section{Figure 3.}

\subsection{Effect of contact time}

Biosorption of the metal ions on hemp was studied over a range of time (1-60 min) and three concentrations $(5,25$ and $100 \mathrm{mg} / \mathrm{L})$ whilst maintaining other parameters constant. The plots (Figure 4) representing the metal abatement can be split in three distinct regions: the first indicates instantaneous biosorption of the metal within 5 min of contact time suggesting rapid surface adsorption and external diffusion; the second shows a gradual equilibrium (between 5 - $10 \mathrm{~min}$ ) and the third (after $10 \mathrm{~min}$ ) indicates the equilibrium state. The kinetics of biosorption were fast and independent of the metal concentration with equilibrium reached in 
$10 \mathrm{~min}$ for all metals. It is also interesting to note that the plots are single, smooth and continuous, leading to saturation, suggesting the possible monolayer coverage of metal on the surface of the biosorbent, and this could confirm the applicability of the Langmuir model.

Indeed, interactions involved were analyzed through classical kinetic and equilibrium models used in the literature. The experimental data suit pseudo-second order kinetics with three biosorption stages (data not published). The Langmuir equilibrium model predicted the following maximum capacities $\left(\mathrm{q}_{\max } \mathrm{mg} / \mathrm{g}\right)$ of 27.47, 14.64, 10.59, 7.99, 7.85, 7.87, 6.53, 6.38 and $4.55 \mathrm{mg} / \mathrm{g}$ biosorbent for $\mathrm{Cd}, \mathrm{Cu}, \mathrm{Zn}, \mathrm{Co}, \mathrm{Fe}, \mathrm{Ni}, \mathrm{Cr}, \mathrm{Al}$ and $\mathrm{Mn}$, respectively. A direct comparison of literature data using different hemp materials is not possible since both biosorbents and experimental conditions are different. Nevertheless, it was observed that the $\mathrm{q}_{\max }$ values of the proposed biosorbent were comparable to those of the other available hempbased materials for metal removal (Table 4).

\section{Figure 4.}

\section{Table 4}

\subsection{Effect of $p H$}

The effect of solution $\mathrm{pH}$ on metal abatement was studied by varying the initial $\mathrm{pH}$ between $1-6$, keeping the other parameters constant. The $\mathrm{pH}$ behavior of all metals was similar (Figure 5). The percentage removal was strongly $\mathrm{pH}$-dependent in the $\mathrm{pH}$ range 1-4 whereas the performances were independent between $\mathrm{pH} 4$ and 6 . At $\mathrm{pH}$ lower than 3 , the abatements decreased drastically due to the competition of $\mathrm{H}^{+}$, except for $\mathrm{Pb}$ and $\mathrm{Cu} . \mathrm{A}$ similar trend was reported for the adsorption of $\mathrm{Ag}, \mathrm{Cd}$, Co, and $\mathrm{Zn}$ by hemp fibres by Păduraru and Tofan ${ }^{12}$, Tofan et al. ${ }^{13,14}$, Pejić et al. ${ }^{16,17}$, and Rezić. ${ }^{18}$

\section{Figure 5.}

\subsection{Elimination and regeneration}

Like all agricultural materials, after biosorption the felt as a low cost material can be incinerated to a much smaller volume of ash and/or recovery of biosorbed metal. ${ }^{23}$ Regeneration is another solution: since the interactions between the metal and material were driven by weak interactions, acidic solutions can be used for the regeneration. Thus using a $0.1 \mathrm{~mol} / \mathrm{L} \mathrm{HCl}$ solution, the material was easily regenerated. After several adsorptionregeneration cycles $(n=5)$, the performance remained unchanged, showing the good reproducibility of the data. 


\subsection{Test with real effluents}

Table 3 reported the minimal and maximal values obtained during the two campaigns of sampling. For each campaign, four effluents, each representative of a whole day's activity of the plant, were sampled on 4 consecutive days. The $\mathrm{pH}$ values of the effluents were found to be relatively stable at around $\mathrm{pH}=4.9 \pm 0.1$, which was the mean value for eight samples. Analytical monitoring of these effluents showed that 14 metals were found at least once: Al, $\mathrm{Cd}, \mathrm{Co}, \mathrm{Cu}, \mathrm{Cr}, \mathrm{Fe}, \mathrm{Li}, \mathrm{Mn}, \mathrm{Ni}, \mathrm{Pb}, \mathrm{Sn}, \mathrm{Sr}, \mathrm{Ti}$, and $\mathrm{Zn}$. Of the 14 metals founds, 8 systematically occurred at detectable levels, i.e. $\mathrm{Al}, \mathrm{Co}, \mathrm{Cu}, \mathrm{Cr}, \mathrm{Fe}, \mathrm{Mn}, \mathrm{Ni}$ and $\mathrm{Zn}$. Other metals such as $\mathrm{Ag}, \mathrm{As}, \mathrm{Ba}, \mathrm{Hg}, \mathrm{Mo}, \mathrm{Pd}, \mathrm{Pt}, \mathrm{Sb}, \mathrm{Se}, \mathrm{Tl}, \mathrm{V}$, and $\mathrm{W}$ were below the QL. Eight other substances were identified and quantified for the two campaigns: $\mathrm{Ca}, \mathrm{K}, \mathrm{Mg}, \mathrm{Na}, \mathrm{P}, \mathrm{S}$, $\mathrm{Si}$, and $\mathrm{B}$. These results demonstrated that real effluents contained a high inorganic load. It is also important to note that the metal load was quantitatively variable (Table 3 ).

The concentrations of the substances obtained after treatment by biosorption are presented in Table 5. These results demonstrated that high levels of metal removal were attained with the use of hemp, allowing water quality criteria regarding industrial discharge waters to be achieved. This treatment led to the almost total elimination of metals such as $\mathrm{Cd}, \mathrm{Pb}, \mathrm{Cu}$, and Ni. The treatment also lowered Fe, Zn, Co, Cr, Al, and Mn (campaign 1) by more than 85\%, $84 \%, 69 \%, 68 \%, 43 \%$ and $26 \%$, respectively. Certain substances such as Na, P, S and B were also eliminated by the process.

The performances of the based-hemp material toward pollutants present in real effluents can be explained by the presence of interactions between the metallic ions and the felt through physisorption (surface adsorption) and chemisorption (electrostatic interactions, precipitation) mechanisms. ${ }^{12,16,19,23-27}$ It was noted that, at the end of the biosorption process, a slight $\mathrm{pH}$ variation between 0.6 and 0.7 units was observed in each experiment, indicating a chemisorption mechanism. To confirm this and to evaluate changes in the surface morphology of the biosorbent, SEM images and elemental analysis using EDS were performed. ${ }^{24}$ The SEM images indicated changes in the morphology of hemp after biosorption (Figure 6). SEM and EDS studies of raw and loaded biosorbent also confirmed the involvement of precipitation in the biosorption process. After biosorption, three of the ten metals (i.e. Al, Fe, and $\mathrm{Zn}$ ) systematically encountered in the effluents and all the other substances except B (i.e. $\mathrm{Ca}, \mathrm{K}, \mathrm{Mg}, \mathrm{Na}, \mathrm{P}, \mathrm{S}, \mathrm{Si}$ ) were detected using EDS at the surface of the fibres constituting the felt. In particular, it is interesting to note also the presence, in the EDS spectra (Figure 6c), of 
agglomerate make up of S, a substance present in real effluents. Thus the felt was also useful to eliminate substances other than metals.

\section{Table 5}

\section{Figure 6.}

\subsection{Ecotoxicological analysis of raw and treated effluents}

Toxicity tests were carried out by applying a standard test to discharged industrial effluents and to the same discharged waters after biosorption treatment. The toxicity values of five effluents described in Table 6 showed that effluents were relatively toxic for Daphnia magna. EC50 values ranged from 5 for sample E2 to 44 for sample E3. According to a French guide on the use of bioassays for the quality assessment of environmental samples ${ }^{4,22}$, the effluents were classified between toxic (EC50<50\%) and very toxic (EC50<10\%). After biosorption, the impact on D. magna was reduced indicated by higher EC values (Table 6). Thus removal of pollutants by the treatment obviously decreased the water toxicity. More experiments are in progress to confirm these chemical and biological results.

\section{Table 6.}

\section{Conclusion}

In this study, the potential of a hemp-based felt for biosorption of metals from aqueous solutions and real effluents was explored in a batch system. In controlled conditions, the effect of process parameters such as biosorbent dose, metal concentration, contact time and $\mathrm{pH}$ was examined. The optimum values for biosorbent dosage, contact time and $\mathrm{pH}$ for metal biosorption were $1.5 \mathrm{~g}, 10 \mathrm{~min}$ and 5, respectively. High adsorption capacities were found using these conditions. The maximum adsorption capacities for $\mathrm{Cd}, \mathrm{Cu}, \mathrm{Zn}, \mathrm{Co}, \mathrm{Fe}, \mathrm{Ni}, \mathrm{Cr}, \mathrm{Al}$ and $\mathrm{Mn}$ were 27.47, 14.64, 10.59, 7.99, 7.85, 7.87, 6.53, 6.38 and $4.55 \mathrm{mg} / \mathrm{g}$ of hemp, respectively. Good results were also obtained for real polymetallic effluents containing concentrations ranging from: Fe 6.9 to $24.5 \mathrm{mg} / \mathrm{L}$; Ni 5.55 to $14.3 \mathrm{mg} / \mathrm{L}$; Zn 3.3 to $11.6 \mathrm{mg} / \mathrm{L}$; Al 1.1 to $9.6 \mathrm{mg} / \mathrm{L} ; \mathrm{Cu} 0.43$ to $5.5 \mathrm{mg} / \mathrm{L}$, and $\mathrm{Cr} 0.35$ to $2.1 \mathrm{mg} / \mathrm{L}$. The hemp was able to remove, in most cases $75-80 \%$ of metal load, allowing water quality criteria regarding industrial discharge waters containing these six metals to be achieved. Ecotoxicological tests also confirmed the efficiency of the biosorption to radically decrease the effluent toxicity. The study of the interactions involved in the biosorption process was studied by employing SEM 
and EDS techniques which revealed that both surface interactions and precipitation participate in metal removal from aqueous solutions. The next step will consist of carrying out a semiindustrial scale test to investigate the feasibility of its implementation on an industrial scale.

\section{Acknowledgments}

Authors thank the Agence de l'Eau, Région Franche-Comté and FEDER for financial support (NIRHOFEX Program 2013-2017 - 'Innovative materials for wastewater treatment').

\section{References}

1 B. Volesky, Biosorption of Metals, CRC Press, Boca Raton FL, (1990).

2 B. Volesky Sorption and Biosorption, BV-Sorbex, Inc., Montreal, (2004).

3 J. Wase, C. Forster C Biosorbents for Metal Ions, Taylor \& Francis, Bristol, (1997).

4 G. Crini, P.M. Badot. Sorption Processes and Pollution, PUFC, Besançon, (2010).

5 R. Dhankhar and A. Hooda, Fungal biosorption - An alternative to meet the challenges of heavy metal pollution in aqueous solutions. Environ. Technol. 5: 467-491 (2011).

6 A. Mudhoo, V.K. Garg and S.B. Wang, Removal of heavy metals by biosorption. Environ. Chem. Lett. 10: 109-117 (2012).

7 M. Fomina and G.M. Gadd, Biosorption: current perspectives on concept, definition and application. Bioresour. Technol. 160: 3-14 (2014).

8 M. Gorska, Z. Hubicki, G. Wojcik and P. Rusek, Biosorption. An environmentally friendly method for removal and recovery of precious metals. Przemysl Chemiczny. 93: 17501753 (2014).

9 M. Vandenbossche, M. Jimenez, M. Casetta, M. Traisnel, Remediation of heavy metals by biomolecules: A review. Critical Rev. Environ. Sci. Technol. 45: 1644-1704 (2015).

10 P. Bouloc, Hemp: Industrial production and uses, CABI, Oxfordshire, 2013.

11 L. Tofan, C. Păduraru, Sorption studies of $\mathrm{Ag}(\mathrm{I}), \mathrm{Cd}(\mathrm{II})$ and $\mathrm{Pb}(\mathrm{II})$ ions on sulphydryl hemp fibers, Croat. Chem. Acta 77: 581-586 (2004).

12 C. Păduraru, L. Tofan, Investigations on the possibility of natural hemp fibers use for Zn(II) removal from wastewaters. Environ. Eng. Manage. J. 7: 687-693 (2008).

13 L. Tofan, C. Teodosiu, C. Păduraru, R. Wenkert, Cobalt(II) removal from aqueous solutions by natural hemp fibers: batch and fixed-bed columns studies. Appl. Surface Sci. 285: 33-39 (2013).

14 L. Tofan, C. Păduraru, C. Teodosiu, O. Toma, Fixed bed columns study on the removal of chromium (III) ions from aqueous solutions by hemp fibers with improved sorption performance. Cellulose Chem. Technol. 49: 219-229 (2015).

15 L. Tofan, C. Păduraru, O. Toma, Zinc remediation of aqueous solutions by natural hemp fibers: batch desorption/regeneration study. Des. Water Treatment 57: 12644-12652 (2016). 
16 B.M. Pejić, M.M. Vukčević, M.P. Kostić, P.D. P.D. Skundric, Biosorption of heavy metal ions from aqueous solutions by short hemp fibers: Effect of chemical composition. $J$. Hazard. Mater. 164: 146-153 (2009).

17 B.M. Pejić, M.M. Vukčević, I.D. Pajić-Lijaković, M.D. Laušević, M.M. Kostić, Mathematical modeling of heavy metal ions $\left(\mathrm{Cd}^{2+}, \mathrm{Zn}^{2+}\right.$ and $\left.\mathrm{Pb}^{2+}\right)$ biosorption by chemically modified short hemp fibers. Chem. Eng. J. 172: 354-360 (2011).

18 I. Rezić, Cellulosic fibers - Biosorptive materials and indicators of heavy metal pollution. Microchem. J. 107: 63-69 (2013).

19 G.Z. Kyzas, Z. Terzopoulou, V. Nikolaidis, E. Alexopoulou, D.N. Bikiaris, Low-cost hemp biomaterials for nickel ions removal from aqueous solutions. J. Mol. Liq. 209: 209218 (2015).

20 J. Bugnet, N. Morin-Crini, C. Cosentino, G. Chanet, P. Winterton, G. Crini, Hemp decontamination of poly-metallic aqueous solutions. Environ. Eng. Manage. J. 16: 535542 (2017).

21 E. Euvrard, N. Morin-Crini, C. Druart, A. Poupeney, G. Crini, Monitoring metal ions present in the effluent discharged from a surface treatment plant: Analytical results. CR. Chimie. 17: 1197-1202 (2014).

22 C. Druart, N. Morin-Crini, E. Euvrard, G. Crini, Chemical and ecotoxicological monitoring of discharge water from a metal-finishing factory. Environ. Process. 3: 59-72 (2016).

23 S. Loiacono, N. Morin-Crini, C. Cosentino, G. Torri, G. Chanet, P. Winterton, G. Crini, Simultaneous removal of $\mathrm{Cd}, \mathrm{Co}, \mathrm{Cu}, \mathrm{Mn}, \mathrm{Ni}$ and $\mathrm{Zn}$ from synthetic solutions on a hempbased felt: Experimental design. J. Appl. Polym. Sci. 134: 1-10 (2017).

24 S. Loiacono, G. Crini, B. Martel, G. Chanet, C. Cosentino, M. Raschetti, V. Placet, G. Torri, N. Morin-Crini, Simultaneous removal of $\mathrm{Cd}, \mathrm{Co}, \mathrm{Cu}, \mathrm{Mn}, \mathrm{Ni}$ and $\mathrm{Zn}$ from synthetic solutions on a hemp-based felt. 2: Chemical modification. J. Appl. Polym. Sci. 134: 1-14 (2017).

25 M. Balintova, M. Holub, N. Stevulova, J. Cigasova, M. Tesarcikova, Sorption in acidic environment - Biosorbents in comparison with commercial adsorbents. Chem. Eng. Trans. 39: 625-630 (2014).

26 T.S. Anirudhan, N.B. Fernandez, M.D. Mullassery, Removal of $\mathrm{Cd}(\mathrm{II})$ ions from aqueous solution using a cation exchanger derived from banana stem. J. Chem. Technol. Biotechnol. 87: 714-722 (2006).

27 D.W. O'Connell, C. Birkinshaw, T.F. O'Dwyer, A modified cellulose adsorbent for the removal of nickel(II) from aqueous solutions. J. Chem. Technol. Biotechnol. 81: 18201828 (2006). 


\section{Tables}

Table 1

Characteristics of hemp-based material.

\begin{tabular}{|l|l|}
\hline Thick & about $5 \mathrm{~mm}$ \\
Cellulose & $75 \%$ \\
Hemicellulose & $15 \%$ \\
Lignin & $3 \%$ \\
Pectins & $5 \%$ \\
$\% \mathrm{C}$ & 41.4 \\
$\% \mathrm{~N}$ & 0.28 \\
$\% \mathrm{~S}$ & 0.06 \\
\hline
\end{tabular}

\section{Table 2}

Minima and maxima ( \pm standard deviation) for several pollutants over four real effluents $(\mathrm{RE})$ during the two sampling campaigns (four samples taken on four consecutive days, representative samples of a daily activity; the results are expressed in concentration in $\mathrm{mg} / \mathrm{L}$; $\mathrm{pH}$ measured at $20^{\circ} \mathrm{C}$ ).

\begin{tabular}{|c|c|c|}
\hline Parameter / Pollutant & Campaign 1 & Campaign 2 \\
\hline Samples & RE1, RE2 RE3, RE4 & RE5, RE6 RE7, RE8 \\
\hline pH & $4.7-5.1(0.2)$ & $4.6-5.1(0.2)$ \\
\hline Al & $1.99-9.6(3.5)$ & $1.1-3.74(1)$ \\
\hline Cd & $<$ QL-0.25 (0.1) & $<$ QL-0.16 (0.07) \\
\hline Co & $3.36-7.55(2.4)$ & $7.3-13.34(2.3)$ \\
\hline $\mathrm{Cr}$ & $0.35-2.1(0.8)$ & $0.45-0.74(0.1)$ \\
\hline $\mathrm{Cu}$ & $0.97-5.5(2.3)$ & $0.43-1.61(0.4)$ \\
\hline Fe & $8.7-24.5(7.6)$ & $6.9-14.4(3)$ \\
\hline Mn & $4.8-22.3(8.3)$ & $3.99-10.1(2.6)$ \\
\hline $\mathbf{N i}$ & $5.55-14.3(4.1)$ & $5.99-8.1(0.8)$ \\
\hline $\mathbf{P b}$ & $<$ QL-0.11 (0.05) & $<$ QL-0.019 (0.02) \\
\hline Zn & $5.9-11.6(2.6)$ & $3.3-9.1(2.2)$ \\
\hline $\mathbf{L i}$ & $<$ QL-0.52 (0.27) & $<\mathrm{QL}-0.1(0.04)$ \\
\hline Sn & $<$ QL-1.95 (1.02) & $0.17-0.37(0.08)$ \\
\hline $\mathrm{Sr}$ & $<$ QL-0.91 (0.41) & $<$ QL-0.74 (0.27) \\
\hline $\mathbf{T i}$ & $0.44-3.25(1.2)$ & $<$ QL-0.47 (0.21) \\
\hline Ca & $438-610(89)$ & $295-457(57)$ \\
\hline $\mathbf{K}$ & $22.7-44.6(9.5)$ & $19.7-34.3(5.9)$ \\
\hline Mg & $85-210(64)$ & $75-132(22)$ \\
\hline $\mathrm{Na}$ & $260-460(104)$ & $163-209(16.7)$ \\
\hline $\mathbf{P}$ & $2.98-7.91(2.5)$ & $1-1.97(0.4)$ \\
\hline S & $9.15-40.5(12.9)$ & $7.88-29.4(7.9)$ \\
\hline $\mathrm{Si}$ & $7.88-31.2(10.2)$ & $8.5-13.7(1.9)$ \\
\hline B & $21.2-105(34.9)$ & $21.2-40(7.8)$ \\
\hline
\end{tabular}




\section{Table 3}

Metal ion characteristics.

\begin{tabular}{|c|c|c|c|c|c|c|c|c|c|c|}
\hline & $\mathrm{Pb}(\mathrm{II})$ & $\mathrm{Cd}(\mathrm{II})$ & $\mathrm{Cu}(\mathrm{II})$ & $\mathrm{Zn}(\mathrm{II})$ & $\mathrm{Ni}(\mathrm{II})$ & $\mathrm{Co}(\mathrm{II})$ & $\mathrm{Fe}(\mathrm{II})$ & $\mathrm{Cr}(\mathrm{III})$ & $\mathrm{Al}(\mathrm{III})$ & $\mathrm{Mn}(\mathrm{II})$ \\
\hline Allred-Rochow EN $^{1}$ & 1.55 & 1.49 & 1.75 & 1.66 & 1.75 & 1.7 & 1.64 & 1.56 & 1.47 & 1.6 \\
$\mathrm{MW}^{2}$ & 207.2 & 112.4 & 63.5 & 65.3 & 58.7 & 58.9 & 55.85 & 51.99 & 26.9 & 54.9 \\
Ionic radius $^{3}$ & 120 & 97 & 72 & 74 & 69 & 72 & 74 & 63 & 51 & 80 \\
\hline
\end{tabular}

${ }^{1}$ Allred-Rochow electronegativity

${ }^{2}$ molar mass in $\mathrm{g} / \mathrm{mol}$

${ }^{3}$ in pm

\section{Table 4}

Adsorption capacities ( $\mathrm{q}_{\max }$ in $\mathrm{mg} / \mathrm{g}$ ) for various metals using hemp.

\begin{tabular}{|l|l|l|l|}
\hline Metal & Type of biosorbent & qmax $_{\text {mat }}$ & Reference \\
\hline $\mathrm{Al}$ & Felt & 6.38 & this study \\
$\mathrm{Cd}$ & Felt & 27.47 & this study \\
$\mathrm{Cd}$ & Fibres & 2.5909 & {$[11]$} \\
$\mathrm{Co}$ & Fibres & 13.58 & {$[13]$} \\
$\mathrm{Co}$ & Felt & 7.99 & this study \\
$\mathrm{Cr}$ & Felt & 6.53 & this study \\
$\mathrm{Cr}$ & Fibres & 4.006 & {$[12]$} \\
$\mathrm{Cu}$ & Felt & 14.64 & this study \\
$\mathrm{Cu}$ & Fibres & 9.0735 & {$[12]$} \\
$\mathrm{Cu}$ & Shives & 3.91 & {$[25]$} \\
$\mathrm{Fe}$ & Felt & 7.87 & this study \\
$\mathrm{Mn}$ & Felt & 4.55 & this study \\
$\mathrm{Ni}$ & Fibres & 206 & {$[19]$} \\
$\mathrm{Ni}$ & Shives & 160 & {$[19]$} \\
$\mathrm{Ni}$ & Felt & 7.85 & this study \\
$\mathrm{Pb}$ & Fibres & 25.05 & {$[13]$} \\
$\mathrm{Zn}$ & Fibres & 21.047 & {$[12]$} \\
$\mathrm{Zn}$ & Felt & 10.59 & this study \\
\hline
\end{tabular}


Table 5

Comparisons of the level of several pollutants present in the industrial effluents before (raw effluents) and after treatment (treated effluents) by biosorption on hemp (the results are expressed as a concentration range deviation minima and maxima ( \pm standard deviation) and as a $\%$ mean abatement \pm standard deviation for the 4 samples of the two campaigns; the concentrations are expressed in $\mathrm{mg} / \mathrm{L} ; \mathrm{pH}$ measured at $20^{\circ} \mathrm{C}$ ).

\begin{tabular}{|c|c|c|c|c|c|c|}
\hline & \multicolumn{3}{|c|}{ Campaign 1} & \multicolumn{3}{|c|}{ Campaign 2} \\
\hline Samples & raw & treated & & raw & treated & \\
\hline $\begin{array}{l}\text { Parameter } \\
\text { / Pollutant }\end{array}$ & concentration & concentration & abatement & concentration & concentration & abatement \\
\hline pH & $4.7-5.1(0.2)$ & $5.3-5.8(0.2)$ & & $4.6-5.1(0.2)$ & $5.2-5.8(0.3)$ & \\
\hline Al & $1.99-9.6(3.5)$ & $1.25-4.87(1.7)$ & $43 \pm 5$ & $1.1-3.74(1)$ & $0.6-2.12(1)$ & $49 \pm 7$ \\
\hline Cd & $<\mathrm{QL}-0.25(0.1)$ & $<\mathrm{QL}$ & 100 & $<$ QL-0.16 (0.07) & $<\mathrm{QL}$ & 100 \\
\hline Co & $3.36-7.55(2.4)$ & $0.8-3.36(1.1)$ & $69 \pm 6$ & $7.3-13.34(2.3)$ & $2.17-5.01(1.3)$ & $64 \pm 5$ \\
\hline $\mathrm{Cr}$ & $0.35-2.1(0.8)$ & $0.096-0.58(0.3)$ & $68 \pm 6$ & $0.45-0.74(0.1)$ & $0.13-0.21(0.1)$ & $72 \pm 2$ \\
\hline $\mathrm{Cu}$ & $0.97-5.5(2.3)$ & $0.035-0.51(0.2)$ & $92 \pm 3$ & $0.43-1.61(0.4)$ & $0.02-0.24(0.1)$ & $92 \pm 4$ \\
\hline Fe & $8.7-24.5(7.6)$ & $1.01-4.66(71.8)$ & $85 \pm 3$ & $6.9-14.4(3)$ & $0.71-1.36(0.3)$ & $89 \pm 1$ \\
\hline Mn & $4.8-22.3(8.3)$ & $3.14-17.9(6.9)$ & $26 \pm 7$ & $3.99-10.1(2.6)$ & $0.31-0.52(0.1)$ & $23 \pm 10$ \\
\hline $\mathbf{N i}$ & $5.55-14.3(4.1)$ & $0.41-0.74(0.1)$ & $93 \pm 1$ & $5.99-8.1(0.8)$ & $0.31-0.52(0.1)$ & $94 \pm 1$ \\
\hline $\mathbf{P b}$ & $<$ QL-0.11 (0.05) & $<$ QL-0.021 (0.01) & $94 \pm 11$ & $<$ QL-0.019 (0.02) & $<\mathrm{QL}$ & 100 \\
\hline Zn & $5.9-11.6(2.6)$ & $0.78-1.81(0.5)$ & $86 \pm 1$ & $3.3-9.1(2.2)$ & $0.57-1.97(0.61)$ & $84 \pm 5$ \\
\hline $\mathbf{L i}$ & $<$ QL-0.52 (0.27) & $<$ QL-0.09 (0.01) & $78 \pm 6$ & <QL-0.1 (0.04) & $<\mathrm{QL}$ & 100 \\
\hline Sn & $<$ QL-1.95 (1.02) & $<$ QL-1.54 (0.8) & $21 \pm 2$ & $0.17-0.37(0.08)$ & $0.11-0.3(0.08)$ & $20 \pm 11$ \\
\hline Sr & $<$ QL-0.91 (0.41) & $<$ QL-0.66 (0.2) & $41 \pm 12$ & $<\mathrm{QL}-0.74(0.27)$ & $<$ QL-0.33 (0.09) & $37 \pm 18$ \\
\hline $\mathbf{T i}$ & $0.44-3.25(1.2)$ & $0.21-1(0.5)$ & $61 \pm 13$ & $<$ QL-0.47 (0.21) & $<$ QL-0.2 (0.01) & $41 \pm 15$ \\
\hline Ca & $438-610(89)$ & $409-557(79)$ & $8 \pm 1$ & $295-457(57)$ & $280-420(57.3)$ & $7 \pm 1$ \\
\hline $\mathbf{K}$ & $22.7-44.6(9.5)$ & $22-43.9(9.5)$ & $2 \pm 1$ & $19.7-34.3(5.9)$ & $18.9-33.7(6.7)$ & $4 \pm 1$ \\
\hline Mg & $85-210(64)$ & $80-201(61)$ & $5 \pm 1$ & $75-132(22)$ & $72-130(25.9)$ & $4 \pm 2$ \\
\hline $\mathrm{Na}$ & $260-460(104)$ & $175-370(102)$ & $24 \pm 7$ & $163-209$ (16.7) & $100-150(22.5)$ & $30 \pm 9$ \\
\hline $\mathbf{P}$ & $2.98-7.91(2.5)$ & $1.35-4.11(1.3)$ & $47 \pm 10$ & $1-1.97(0.4)$ & $0.22-0.77(0.25)$ & $65 \pm 9$ \\
\hline S & $9.15-40.5$ (12.9) & $6.7-31.2(10.2)$ & $25 \pm 2$ & $7.88-29.4(7.9)$ & $5.35-22.4(7.3)$ & $30 \pm 4$ \\
\hline $\mathbf{S i}$ & 7.88-31.2(10.2) & $7.44-28.9(9.4)$ & $7 \pm 1$ & $8.5-13.7$ (1.9) & $7.78-12.4(1.9)$ & $7 \pm 3$ \\
\hline $\mathbf{B}$ & $21.2-105(34.9)$ & $24.9-90(30.5)$ & $18 \pm 4$ & $21.2-40(7.8)$ & $11.8-31.6(9.4)$ & $33 \pm 11$ \\
\hline
\end{tabular}

Table 6. Total of metals present in solution (in $\mathrm{mg} / \mathrm{L}$ ) before and after biosorption on hemp and toxicity values (expressed by EC50 in percentage of effluent) for Daphnia magna for five samples.

\begin{tabular}{|c|c|c|c|c|}
\hline Sample & \multicolumn{2}{|c|}{ Total of metals ${ }^{*}$ present in solution in $\mathbf{~ m g / L}$} & \multicolumn{2}{c|}{ EC50 in percentage of effluent } \\
\hline & raw effluent & treated effluent & raw effluent & treated effluent \\
\hline E1 & 44.51 & 13.69 & 31 & 70 \\
\hline E2 & 98.93 & 35 & 5 & 44 \\
\hline E4 & 37.7 & 9.74 & 44 & $>90$ \\
\hline E5 & 86.68 & 32.21 & 10 & 71 \\
\hline
\end{tabular}

* $\mathrm{Al}+\mathrm{Cd}+\mathrm{Co}+\mathrm{Cr}+\mathrm{Cu}+\mathrm{Fe}+\mathrm{Mn}+\mathrm{Ni}+\mathrm{Pb}+\mathrm{Zn}+\mathrm{Li}+\mathrm{Sn}+\mathrm{Sr}+\mathrm{Ti}$ 


\section{Figure - Legends}

Figure 1. Effect of initial metal concentration on metal removal (expressed in \% removal) onto hemp-based felt (solutions prepared with metal sulfate salts; conditions: biosorbent dose $1 \mathrm{~g}$, volume of solution $100 \mathrm{~mL}$, contact time $60 \mathrm{~min}$, agitation speed $250 \mathrm{rpm}, \mathrm{pH}=5$, temperature $20^{\circ} \mathrm{C}$, and $\mathrm{n}=3$ ).

Figure 2. Effect of counter-ions on biosorption of $\mathrm{Ni}$ and $\mathrm{Co}$ ions (expressed in \% removal) by hemp-based felt using different metal salts (conditions: biosorbent dose $=1 \mathrm{~g}$, volume of solution $=100 \mathrm{~mL}$, contact time $=60 \mathrm{~min}$, agitation speed $=250 \mathrm{rpm}, \mathrm{pH}=5$, temperature $=$ $20^{\circ} \mathrm{C}$, and $\mathrm{n}=3$ ).

Figure 3. Removal (\%) vs. hemp dose at different initial metal concentrations (others conditions: volume of solution $100 \mathrm{~mL}$, contact time $60 \mathrm{~min}$, agitation speed $250 \mathrm{rpm}$, temperature $20^{\circ} \mathrm{C}, \mathrm{pH}=5$, and $\mathrm{n}=3$ ).

Figure 4. Kinetics of metal removal (\%) by hemp at three different initial metal concentrations (others conditions: adsorbent dose $1 \mathrm{~g}$, volume of solution $100 \mathrm{~mL}$, agitation speed $250 \mathrm{rpm}$, temperature $20^{\circ} \mathrm{C}, \mathrm{pH}=5$, and $\mathrm{n}=3$ ).

Figure 5. Influence of $\mathrm{pH}$ on the abatement of ten metals (expressed in $\%$ removal) by hemp (conditions: adsorbent $1 \mathrm{~g}$, volume of the solution $100 \mathrm{~mL}$, initial metal concentration 25 $\mathrm{mg} / \mathrm{L})$.

Figure 6. SEM images (left) and EDS (right) spectra of the felt before (a) and after (b,c) biosorption. The red arrow on the SEM image (c) shows agglomerates at the surface of the fibre. 


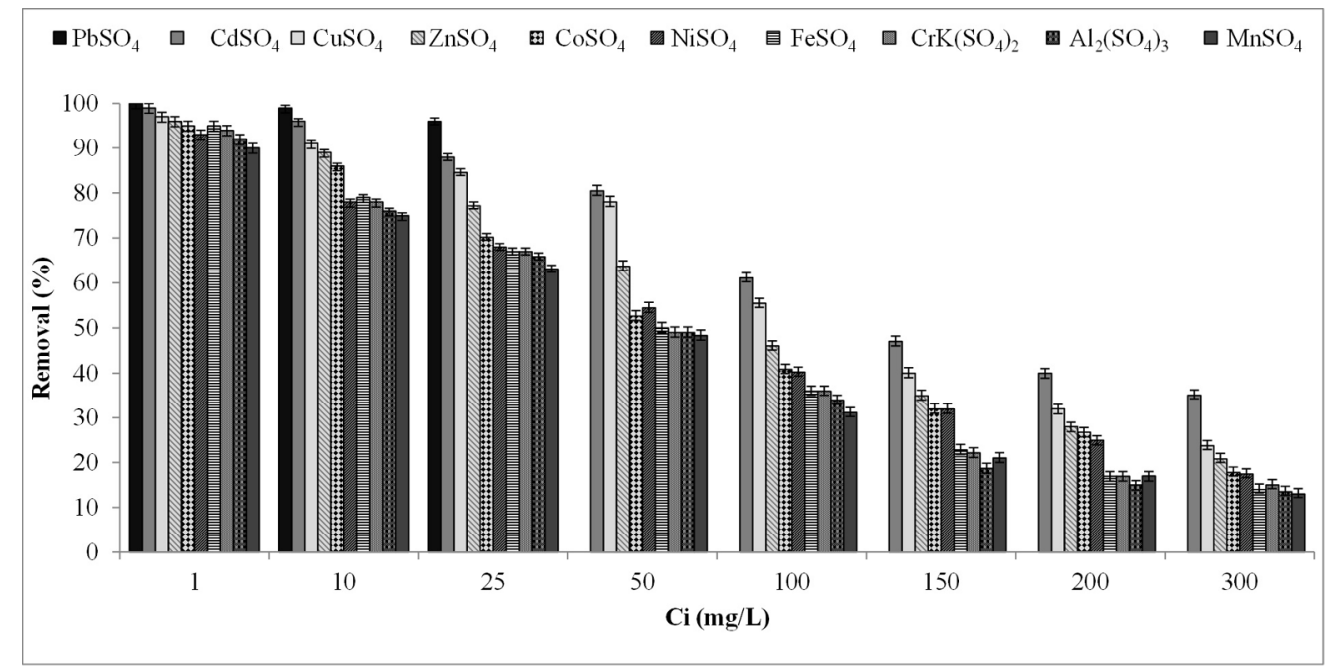

Figure 1. Effect of initial metal concentration on metal removal (expressed in \% removal) onto hemp-based felt (solutions prepared with metal sulfate salts; conditions: biosorbent dose $1 \mathrm{~g}$, volume of solution $100 \mathrm{~mL}$, contact time $60 \mathrm{~min}$, agitation speed $250 \mathrm{rpm}, \mathrm{pH}=5$, temperature $20^{\circ} \mathrm{C}$, and $\mathrm{n}=3$ ). 

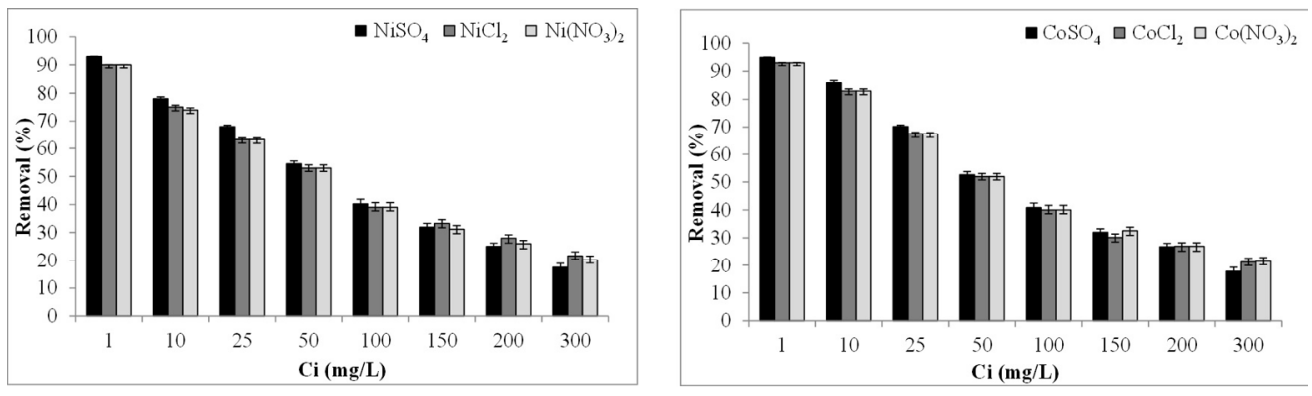

Figure 2. Effect of counter-ions on biosorption of $\mathrm{Ni}$ and $\mathrm{Co}$ ions (expressed in \% removal) by hemp-based felt using different metal salts (conditions: biosorbent dose $=1 \mathrm{~g}$, volume of solution $=100 \mathrm{~mL}$, contact time $=60 \mathrm{~min}$, agitation speed $=250 \mathrm{rpm}, \mathrm{pH}=5$, temperature $=20^{\circ} \mathrm{C}$, and $\mathrm{n}=3$ ). 


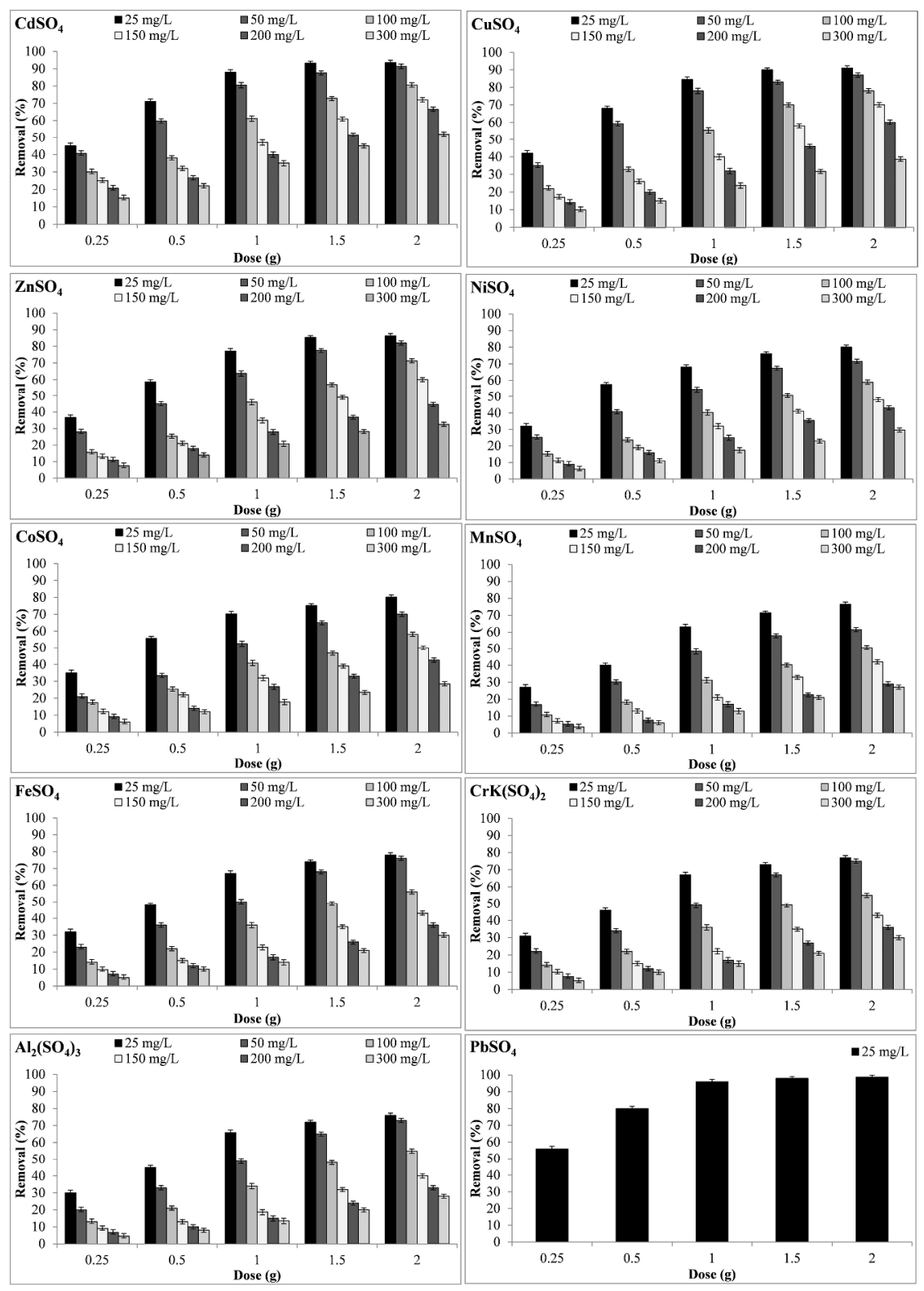

Figure 3. Removal (\%) vs. hemp dose at different initial metal concentrations (others conditions: volume of solution $100 \mathrm{~mL}$, contact time $60 \mathrm{~min}$, agitation speed $250 \mathrm{rpm}$, temperature $20^{\circ} \mathrm{C}, \mathrm{pH}=5$, and $\mathrm{n}=3$ ). 


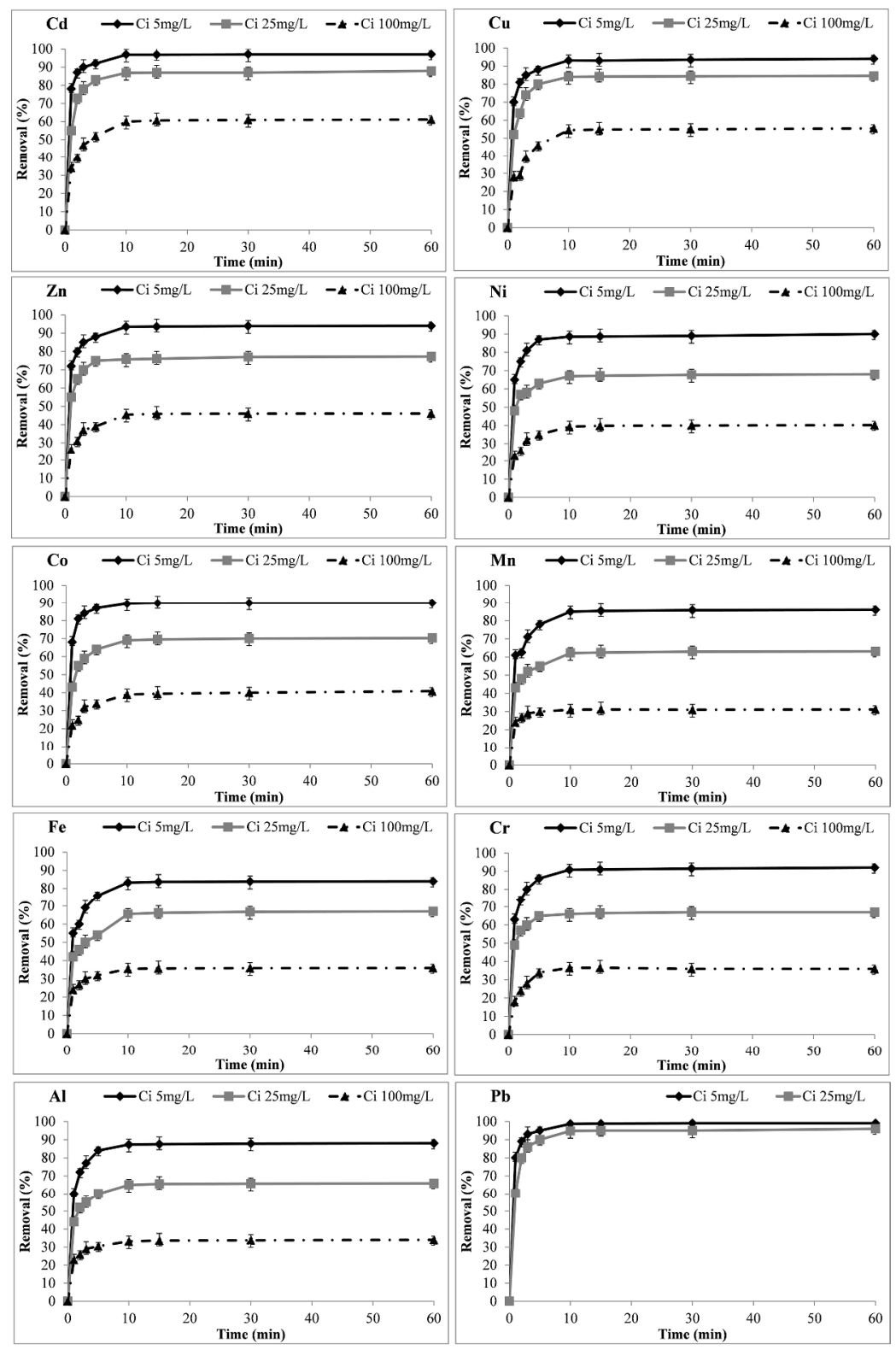

Figure 4. Kinetics of metal removal (\%) by hemp at three different initial metal concentrations (others conditions: adsorbent dose $1 \mathrm{~g}$, volume of solution $100 \mathrm{~mL}$, agitation speed $250 \mathrm{rpm}$, temperature $20^{\circ} \mathrm{C}, \mathrm{pH}$ $=5$, and $\mathrm{n}=3$ ). 


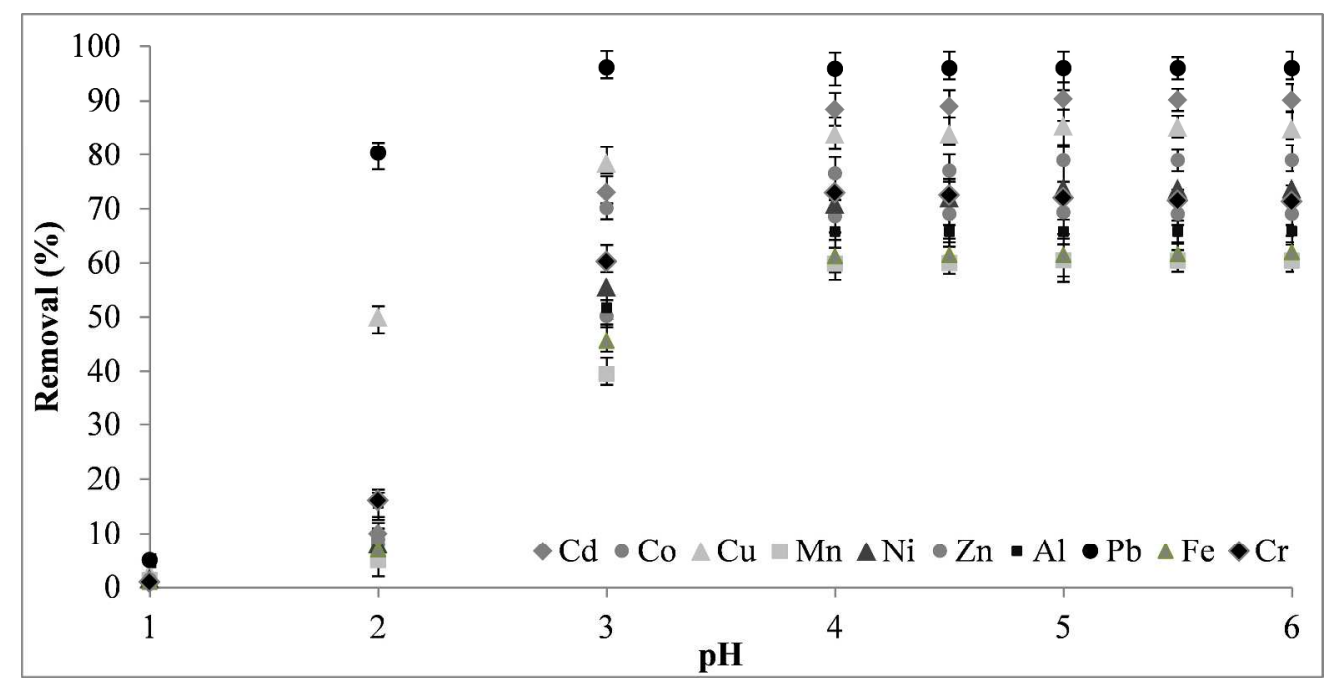

Figure 5. Influence of $\mathrm{pH}$ on the abatement of ten metals (expressed in \% removal) by hemp (conditions: adsorbent $1 \mathrm{~g}$, volume of the solution $100 \mathrm{~mL}$, initial metal concentration $25 \mathrm{mg} / \mathrm{L}$ ).

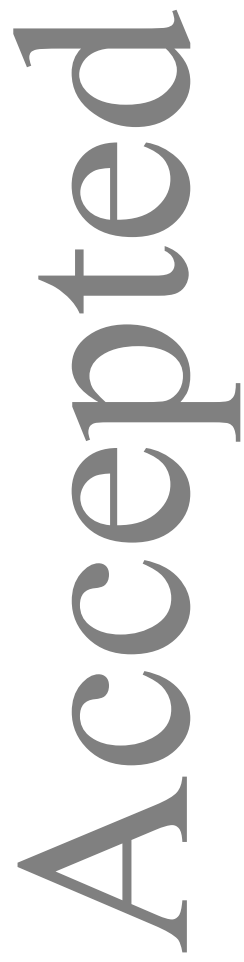



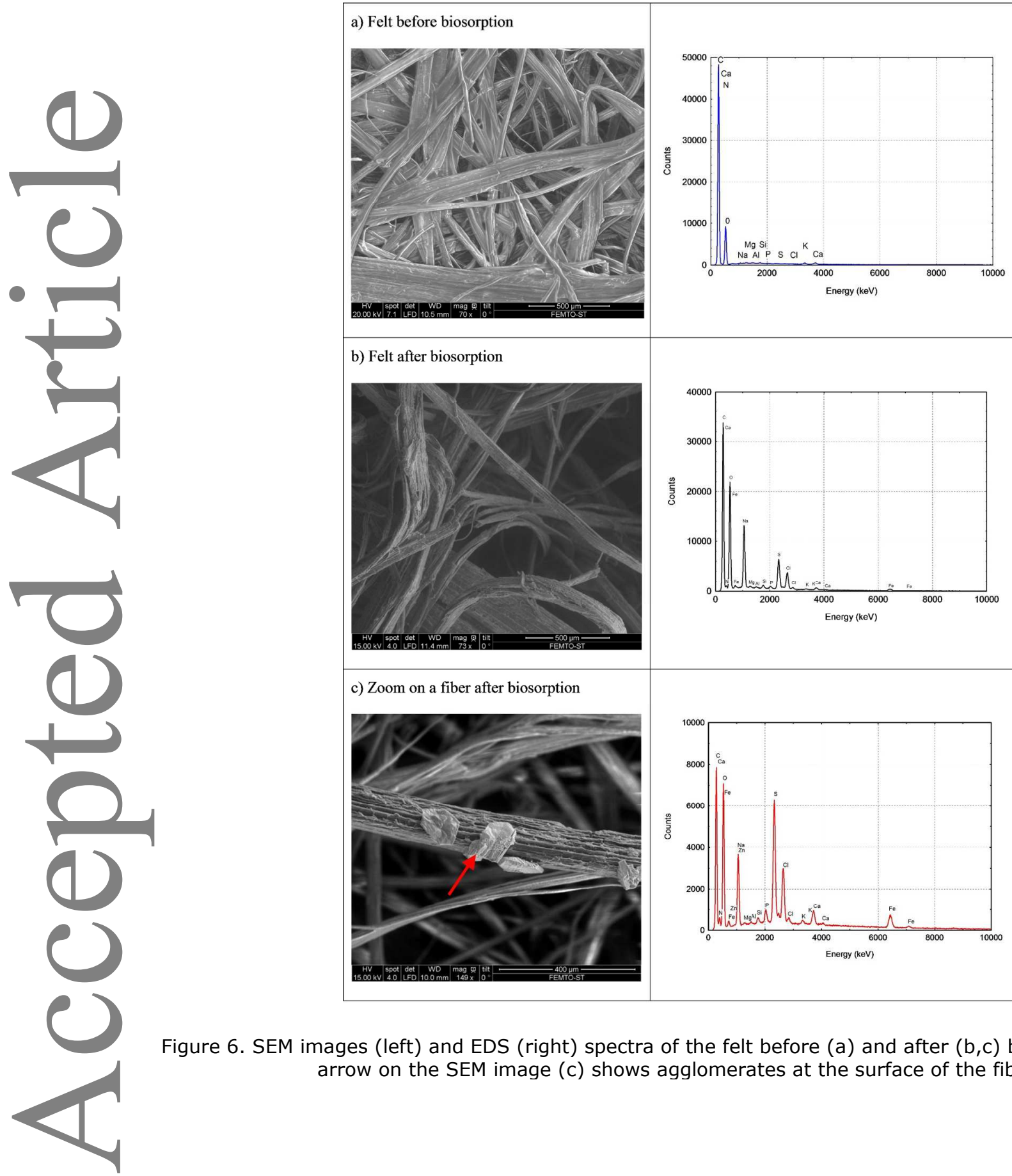

b) Felt after biosorption
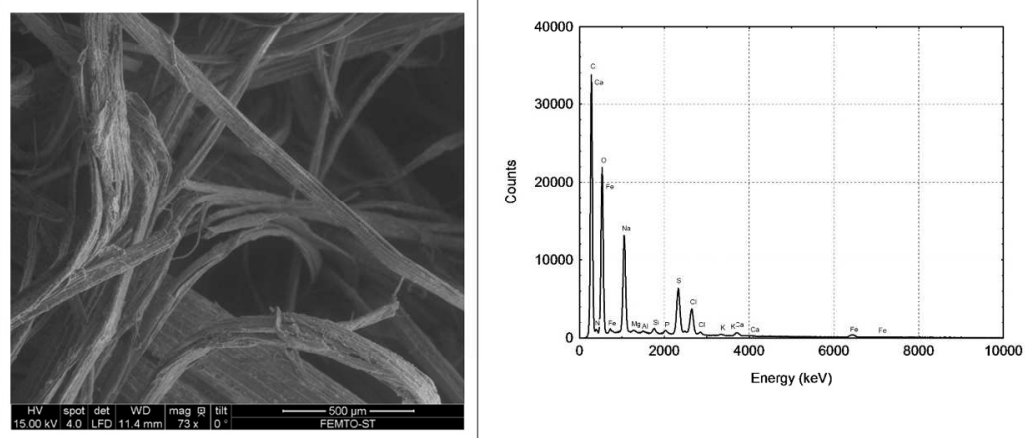

c) Zoom on a fiber after biosorption
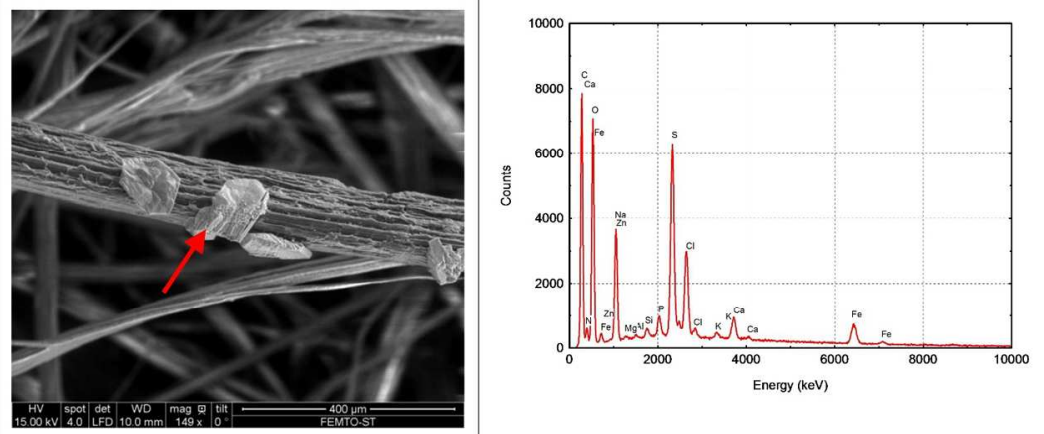

Figure 6. SEM images (left) and EDS (right) spectra of the felt before $(a)$ and after $(b, c)$ biosorption. The red arrow on the SEM image (c) shows agglomerates at the surface of the fibre. 